\title{
THE MODIFICATION METHOD OF CORRECTION OF HYGIENIC BEHAVIOR OF HONEУBEES
}

\section{Kysterna Olesia ${ }^{1}$ Ignatieva Olga ${ }^{2}$}

DOI: https://doi.org/10.30525/978-9934-571-89-3_98

One of the most important ways of preventing from the honeybee brood diseases is to stimulate the reserve protective properties of bee colonies. Hygienic behavior of honey bees is a method of a colony self-defense, characterized by the removal of sick or damaged larvae on the frames with a brood and is performed by the worker bees [1, p. 226-227; 2, p. 4].

It is known that the hygienic behavior is formed by a breed peculiarity, colony strength and natural or artificial stimulation by feeding [2, p. 74-81].

In our time, it has become important to pay attention to the natural protective mechanisms of bees. In addition, the use of various chemotherapeutic agents is hazardous to the environment and beekeeping produce. While studying the bee brood diseases and having a lot of drugs, we consider it necessary to work out some rational approaches to the natural stimulation of the reserve properties of bee colonies that could influence the spread of bee diseases [3].

The assertion that it's possible to reduce the sickness rate and the application of the therapeutic agents due to the hygienic ability of bees is being checked by a lot of scientists According to the classification, a bee colony is considered hygienic if it is able to remove $90 \%$ of the affected brood within 24 hours (other authors claim $70 \%$ barrier). If a bee colony removes less than $40-70 \%$ of the cells on the brood frame it is considered a critical hygienic ability [4, p. 169-186]. It's possible to strengthen the hygienic behavior of bees through the application of stimulants.

The method of intensification of the natural protection of bees by means of correction of feeding methods hadn't been used. The efficiency of this method was proved and patented in the previous studies [5, p. 4].

The "modified method" of feeding up the bee colonies consists in the simultaneous combination of the aerosol spraying and natural feeding of the stimulants. This method has been investigated on the drugs that may lose their relevance due to the termination of their licensing in Ukraine [5, p. 4].

Therefore, the purpose of our research has become a comparative assessment of the hygienic behavior of bees where such combined feeding technique as $50 \%$ sugar syrup without stimulants was applied.

The experiment was carried out on the bee colonies of an aboriginal Ukrainian breed with the queens aged 2 years on a private apiary of Sumy district in April 2018.

The bees are kept in the multiblock hives. The honey flow takes place in the forest and meadow areas with an average level of flowering meliferous plants. Six strong

\footnotetext{
${ }^{1}$ Sumy National Agrarian University, Ukraine

${ }^{2}$ Sumy National Agrarian University, Ukraine 
bee colonies (7-8 beeways) and 6 average bee colonies (with $4-5$ beeways each) were formed and divided into three groups. Of these, the first experimental group (D1, D2) (formed by two strong and two average bee colonies) received 50\% sugar syrup in a dose of $1 \mathrm{ml}$ per $100 \mathrm{ml}$ per beeway in the feeders five times within two weeks in all groups except for the experimental one (K1, K2). In the second experimental group (M 3, M 4) the sugar syrup was used in a "modified way", i.e., the part of a single syrup dose was sprayed from both sides onto the dry honeycombs and with some beebread and honey, the other part was fed up.

Three weeks after the brood appeared, the comparative evaluation of the strength of the bee colonies was made and the hygienic behavior was evaluated by a special test. So, one honeycomb with a sealed brood was chosen in each colony and a segment sized $5 \times 5 \mathrm{~cm}$, equal to 100 cells was marked. There the perforations of cells were made and they were put into the hive again. In 24 hours the number of cleaned cells was estimated. The evaluation criterion of hygienic behavior of bees is: high more than 95\%, sufficient - 90-94\%, medium - 80-89\%; non-hygienic behaviorbelow $70-79 \%$ [7; 13].

Thus, the application of syrup within April in experimental group 1, on the average, facilitated colony strengthening per 1 beeway compared with monitoring. In experimental group 2 - per 2 beeways (Figure 1).

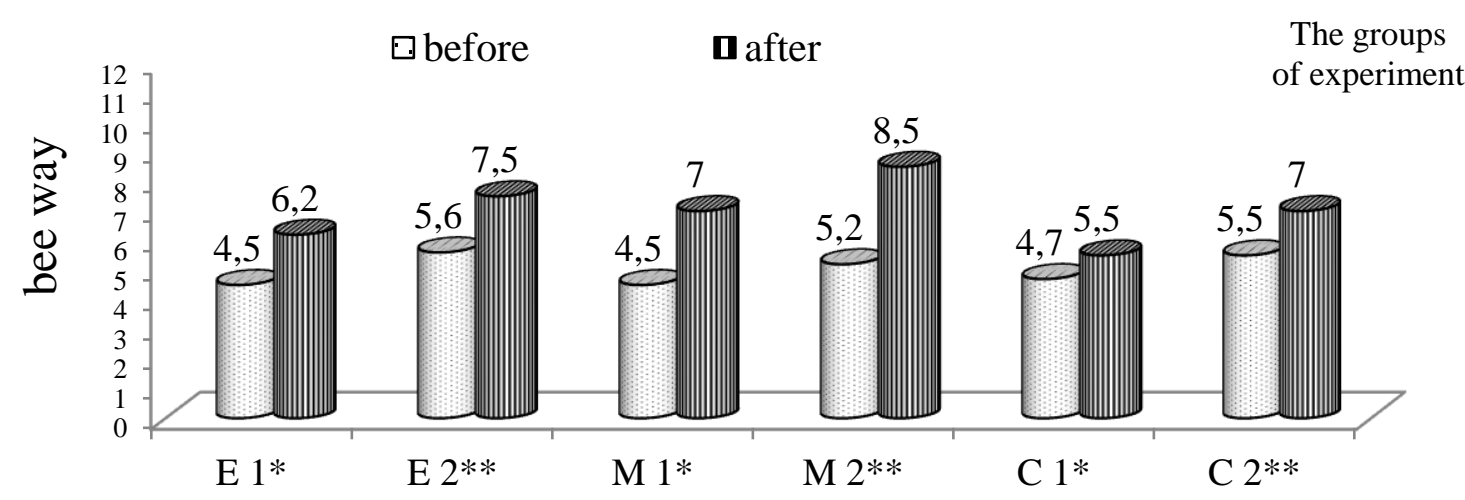

Figure 1. The correlation of strength of bee colonies by different methods of the sugar syrup application: $E 1, M 1, C 1^{*}$-groups with average bee colonies; $E 2, M 2, C 1^{* *-g r o u p s}$ with strong bee colonies. " $E$ " - the experimental groups by the feeding method of syrup application; " $M$ " - the experimental groups by the "modified method" of syrup application; " $C$ " - the control groups without feeding with syrup

As a result of the visual comparison of bee behavior during the application of the modified method of feeding it was stated that aerosol spraying enforced bees to take fodder honey, accelerated the obtaining of extra nutrition to the brood and queen, and contributed to cleaning the hive from the dead larvae.

As a result of the "perforation" test it was found out that the strong colonies that received extra nutrition due to the modified method performed sanitary-hygienic 
functions at $82-87 \%$; the colonies receiving syrup in a simple way - at $70-78 \%$; the colonies under control had 64-69\% degree of cleaning (Figure 2).

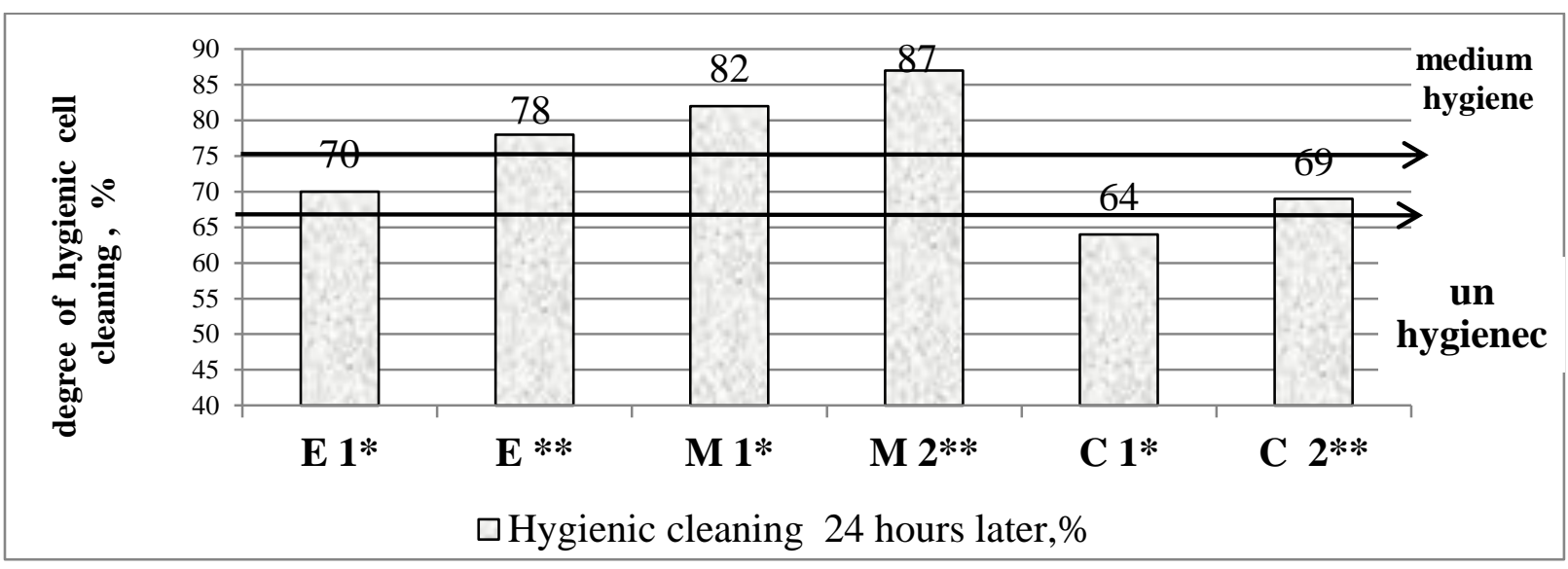

Figure 2. Evaluation of hygienic cleaning of bee colonies by the "perforation test" in different methods of expemental feeding with syrup and control: $E^{*}, M^{*}, C^{*}$ - for explanation, see Figure 1

Parallel with the revision in April, it was found out that before the beginning of the experiment, the degree of Varroozis affection of experimental bee colonies and the colonies under control in weak families was about 2-3\%. The presence of motley brood was 3-4 cells per 100 cells with a brood. Then, after extra nutrition by the modified method the presence of motley brood was $-1-2$; by feeding $-2-3$; under control - 3-4 cells.

Thus it has been established that the "modified method" combining feeding and aerosol spraying of honeycombs with honey, beebread and honeycombs for the future brood, contributes to performing basic vital functions of a bee colony - increasing its strength and hygienic behavior.

The combined feeding technique for extra nutrition of bees compared with the standard one without application of stimulants improves the hygienic behavior of bees by $9-12 \%$, but withot extra nutrition - by $18 \%$, which is an important chain in the prophylaxis of diseases of a honeybee brood.

\section{References:}

1. Rudenko Ye. V. (2006). Znachennia aktyvnosti hihiienichnoi povedinky bdzhil dlia pidvyshchennia produktyvnosti bdzholynykh simei [Significance of activity of hygienic behavior of bees for increase of productivity of bee families]. Naukovyi visnyk Natsionalnoho ahrarnoho universytetu, no. 94., pp. 226-270. (in Ukrainian)

2. Kysterna O.S. (2015). Correction of hygienic activity of bees. The Animal Biology, 17, (2), 74-81.

3. Hrytsenko B.L. (2017). Reading allowed: Ekonomichne modeliuvannia rynku medu 2017. [Economic modeling of the honey market].

4. Spivak M., Gilliam M. (1998). Hygienic behaviour of honey bees and its application for control of brood diseases and Varroa. Part II: Studies on hygienic behaviour since the Rothenbuhler era. Bee World, v. 79, n. 4, p. 169-186. 
5. Kysterna O.S., Musiienko O.V., Musiienko O.V., Chura I.M. (2014). Patent U201401148 Ukraina, MPK (2014.01), A01K 47/00, A01K 53/00. Modyfikovanyi sposib stymuliatsii medonosnykh bdzhil tkanynnym preparatom PDE (platsenta denaturovana emulhovana [Modified method of stimulation of honey bees by tissue drugs PDE (denatured placenta emulsified]. Zaiavnyk i patentovlasnyk Sumskyi natsionalnyi ahrarnyi universytet., no. № 91949 ; zaiavl. 06.02.; opubl. 25.07.2014, Biul. № 14, pp. 4. (in Ukrainian) 